\title{
Once-daily milking during a feed deficit decreases milk production but improves energy status in early lactating grazing dairy cows
}

\author{
J. K. Kay, ${ }^{1}$ C. V. C. Phyn, A. G. Rius, S. R. Morgan, T. M. Grala, and J. R. Roche \\ DairyNZ Ltd., Private Bag 3221, Hamilton 3240, New Zealand
}

\begin{abstract}
The objective of this study was to investigate the effect of milking frequency (MF) at 2 feeding levels (FL) on milk production, body condition score, and metabolic indicators of energy status in grazing dairy cows during early lactation. Multiparous Holstein-Friesian and Holstein-Friesian $\times$ Jersey cows $(\mathrm{n}=120)$ grazed pasture and were milked twice daily $(2 \times)$ from calving until $34 \pm 6 \mathrm{~d}$ in milk (mean \pm standard deviation). Cows were then allocated to 1 of 4 treatments in a $2 \times 2$ factorial arrangement. Treatments consisted of $2 \mathrm{FL}$ : adequately fed [AF; $14.3 \mathrm{~kg}$ dry matter intake (DMI)/cow per d] or underfed (UF; $8.3 \mathrm{~kg}$ of DMI/cow per d) and 2 MF: $2 \times$ or once daily $(1 \times)$. Treatments were imposed for $3 \mathrm{wk}$. After the treatment period, all cows were offered a generous pasture allowance (grazing residuals $>1,600 \mathrm{~kg}$ of dry matter/ha) and milked $2 \times$. During the 3 -wk treatment period, we observed an interaction between FL and MF for energy-corrected milk (ECM), such that the decrease due to $1 \times$ milking was greater in AF than in UF cows (20 and 14\% decrease, respectively). No interactions were found posttreatment. Cows previously UF produced $7 \%$ less ECM than AF cows during wk 4 to 12; however, no subsequent effect was observed of the previous underfeeding. Cows previously milked $1 \times$ produced $5 \%$ less ECM during wk 4 to 12 , and differences remained during wk 13 to 23 . During the 3 -wk treatment period, UF cows lost 0.2 body condition score units ( $1-10$ scale) and this was not affected by $1 \times$ milking. During the treatment period, UF cows had lower plasma glucose, insulin, and insulin-like growth factor I, and greater nonesterified fatty acids and $\beta$-hydroxybutyrate concentrations than AF cows. Cows milked $1 \times$ had greater plasma glucose, insulin, and insulin-like growth factor I, and lower nonesterified fatty acids and $\beta$-hydroxybutyrate concentrations compared with cows milked $2 \times$. In conclusion, energy status was improved by $1 \times$ milking; however,
\end{abstract}

Received September 17, 2012.

Accepted April 22, 2013.

${ }^{1}$ Corresponding author: jane.kay@dairynz.co.nz when UF cows were milked $1 \times$, milk production was reduced by more than underfeeding alone. The immediate and residual responses to $1 \times$ milking need to be considered when using this management strategy during a feed deficit.

Key words: once-daily milking, nutrition, milk production, energy balance

\section{INTRODUCTION}

In pasture-based dairy systems, extreme weather events such as floods, heavy snowfalls, storms, or droughts can result in severe feed deficits. Reports indicate that the number of these extreme weather events will likely increase in the future (Renwick et al., 2010). These conditions threaten low-input seasonal grazing systems, where milk production, reproduction, and animal welfare are dependent on pasture availability and quality. The effects of nutritional stress (reduced pasture quality and quantity) on milk production and energy status have been well researched in grazing dairy cows (Broster, 1974; Bryant and Trigg, 1974; Roche, 2007; Burke et al., 2010), with immediate and longer-term negative effects on milk production, energy balance, and reproduction. Therefore, it is important to investigate the effect of potential mitigation strategies for dealing with feed deficits.

One mitigation strategy that is proposed to alleviate nutritional stress during a feed deficit is milking cows once daily $(\mathbf{1} \times)$ instead of the traditional twicedaily $(\mathbf{2} \times)$ regimen (Auldist and Prosser, 1998; Davis et al., 1999; Rémond et al., 2002; Guinard-Flament et al., 2007). Research results consistently indicate an immediate decrease in milk production of 20 to $30 \%$ with $1 \times$ milking (Davis et al., 1999) but some also indicate an improvement in cow energy balance (Auldist and Prosser, 1998; Rémond et al., 1999, 2002; Patton et al., 2006; Guinard-Flament et al., 2007; McNamara et al., 2008). However, inconsistent results have been reported as to whether the effects of $1 \times$ milking persist beyond the period of reduced milking frequency (MF). Rémond et al. (2002) reported no long-term production losses after 3 wk of $1 \times$ milking, whereas Phyn et al. (2011) and Guinard-Flament et al. (2011) reported 
reduced milk production for up to $26 \mathrm{wk}$ after cows had previously been milked $1 \times$ for $3 \mathrm{wk}$.

Additionally, there are limited published results on the interactions between reduced MF and feeding level (FL; Auldist and Prosser, 1998; Rémond et al., 2002; Guinard-Flament et al., 2007). Data from experiments that did reduce both MF and FL indicate that the immediate negative effects of $1 \times$ milking on milk production are at least partially additive to those of reduced energy intake; however, none of these experiments measured effects beyond the period of reduced MF and intake. In addition, these experiments are limited in their application to pasture-based systems, as cows were milked $1 \times$ for a very short period ( $2 \mathrm{~d}$; Auldist and Prosser, 1998), or fed a TMR in confinement (Rémond et al., 2002; Guinard-Flament et al., 2007), or subjected to a small $(7 \%)$ feed restriction (Rémond et al., 2002). Thus, to the best of our knowledge, no published literature exists on the immediate and carryover effects of $1 \times$ milking during a period of severe nutritional stress in grazing dairy cows.

The primary hypothesis tested in this study was that $1 \times$ milking during a pasture deficit in early lactation would reduce milk production by more than the feed deficit alone and would improve energy balance. The secondary hypothesis was that the effects of both reduced MF and FL on milk production and energy status would extend beyond the treatment period. To test these hypotheses, the effects of $1 \times$ milking at $2 \mathrm{FL}$ on immediate and carryover milk production, BCS, and plasma energy metabolites were measured in grazing dairy cows during early lactation.

\section{MATERIALS AND METHODS}

\section{Animals and Treatments}

The experiment was conducted at the Westpac Taranaki Agricultural Research Station (Hawera, New Zealand) between July 2009 and April 2010. All procedures involving animals were approved by the Ruakura Animal Ethics Committee (Hamilton, New Zealand).

One hundred and twenty multiparous ( $4 \pm 2$ parity; mean $\pm \mathrm{SD})$ Holstein-Friesian $(\mathrm{n}=112)$ and HolsteinFriesian $\times$ Jersey cross cows $(\mathrm{n}=8)$ that calved at a BCS $4.9 \pm 0.3$ (1 to 10 scale) were managed as one herd. Cows were milked $2 \times$ and offered a generous pasture allowance (postgrazing residuals $>1,600 \mathrm{~kg}$ of $\mathrm{DM} / \mathrm{ha}$ measured to ground level), for the first $34 \pm 6$ DIM. Cows were then allocated to 1 of 4 treatments for $3 \mathrm{wk}$ (balanced for milk yield, DIM, breed, and parity) in a $2 \times 2$ factorial arrangement. Treatments consisted of 2 FL: adequately fed (AF), which targeted postgrazing residuals of $>1,600 \mathrm{~kg}$ of $\mathrm{DM} / \mathrm{ha}$ and an average DMI of $15 \mathrm{~kg}$ of DM/cow per d, or underfed (UF), which targeted a $40 \%$ reduction in DMI relative to $\mathrm{AF}$, and $2 \mathrm{MF}: 2 \times$ or $1 \times$. The 4 treatments were $(1) \mathrm{AF} 2 \times,(2)$ $\mathrm{AF} 1 \times$, (3) UF $2 \times$, and (4) UF1 $\times$. Daily milking times were $0700 \mathrm{~h}$ for $1 \times$ and $0700 \mathrm{~h}$ and $1500 \mathrm{~h}$ for $2 \times$.

To reduce variability due to DIM, 2 cohorts within treatment were formed. Cows that calved from July 17 to August $7(\mathrm{n}=66)$ were included in cohort 1 and cows that calved from August 8 to September 1 $(\mathrm{n}=54)$ were included in cohort 2 . Both cohorts were managed identically. Following the 3 -wk treatment periods, all animals were milked $2 \times$ and grazed together with pasture allowances targeting postgrazing residuals $>1,600 \mathrm{~kg}$ of $\mathrm{DM} / \mathrm{ha}$ for $20 \mathrm{wk}$.

\section{Pasture Measurements and Analysis}

Pre- and postgrazing pasture mass was estimated on $3 \mathrm{~d}$ each week during the treatment periods using calibrated visual assessment, and on $1 \mathrm{~d}$ each week for the remainder of the experiment by the same person (Roche, 2007). Representative pasture samples were collected on $5 \mathrm{~d}$ each week by hand-clipping pasture to the predicted grazing height from paddocks immediately before grazing. Samples were bulked weekly and dried at either $100^{\circ} \mathrm{C}$ for $\mathrm{DM}$ determination or $60^{\circ} \mathrm{C}$ for analysis of nutrient composition (Roche, 2007). Metabolizable energy content of the pasture was estimated as described by Roche (2007) and energy intakes (MJ of $\mathrm{ME} /$ cow per $\mathrm{d}$ ) were calculated as the product of pasture DMI and ME.

\section{Grazing Management and Intake}

All cows grazed in the same paddock and were separated by double-stranded electric fences during the 3 -wk treatment period to control pasture allowance and prevent back grazing. To achieve target pasture allowance and DMI, different sized areas were allotted to UF and AF treatments based on pregrazing pasture mass and the desired allowance per cow. At the start of the treatment period, pasture allowances were incrementally increased or decreased over a 3 -d period to achieve the targeted DMI of 15 and $9 \mathrm{~kg}$ of DM/cow per $\mathrm{d}$ in the AF and UF treatments, respectively. All cows were offered a fresh pasture break twice daily at approximately 0800 and $1600 \mathrm{~h}$.

Average daily DMI ( $\mathrm{kg}$ of $\mathrm{DM} / \mathrm{cow}$ per d) was estimated for each treatment, as the product of the difference between pre- and postgrazing mass and area grazed, divided by the number of cows. During the treatment period (wk 1 to 3), pasture allowance, DMI, and energy intake for the AF treatment were $31.4 \pm 3.9$ $\mathrm{kg}$ of $\mathrm{DM} /$ cow per $\mathrm{d}, 14.3 \pm 3.6 \mathrm{~kg}$ of $\mathrm{DM} /$ cow per $\mathrm{d}$, 
and $173 \pm 44 \mathrm{MJ}$ of ME/cow per d, respectively. The same variables for the UF treatment were $14.4 \pm 5.6 \mathrm{~kg}$ of $\mathrm{DM} /$ cow per d, $8.3 \pm 2.9 \mathrm{~kg}$ of $\mathrm{DM} /$ cow per d, and $100 \pm 35 \mathrm{MJ}$ of ME/cow per d, respectively. This represented a $42 \%$ decrease in DM and energy intake for the UF cows. During the posttreatment period, average pasture allowance was $35.2 \pm 6.1 \mathrm{~kg}$ of $\mathrm{DM} /$ cow per $\mathrm{d}$, DMI was $14.1 \pm 4.6 \mathrm{~kg}$ of $\mathrm{DM} /$ cow per $\mathrm{d}$, and energy intakes were $170 \pm 56 \mathrm{MJ}$ of ME/cow per d.

\section{Animal Measurements}

Individual milk yields were recorded at each milking (GEA, Oelde, Germany) and milk samples were collected from the a.m. and p.m. milkings on $1 \mathrm{~d}$ each week. A composite daily sample was formed from the a.m. and p.m. samples based on weight proportionality according to milk yield. From this composite sample, milk composition was determined using Fourier-transform infrared spectroscopy (FT120, Foss Electric, Hillerød, Denmark), and SCC was measured using a cell counter (Fossomatic, Foss Electric). Individual BW and BCS (1-10 scale; Roche et al., 2004) were determined on $1 \mathrm{~d}$ each week for 2 wk pre- until 10 wk posttreatment initiation, and then on $1 \mathrm{~d}$ every $2 \mathrm{wk}$ thereafter. Energy-corrected milk was calculated as follows: [ECM $(\mathrm{kg} /$ cow per $\mathrm{d})=$ milk weight $(\mathrm{kg} /$ cow per $\mathrm{d}) \times(383$ $\times$ fat $\%+242 \times$ protein $\%+783.2) / 3,140]$; Tyrrell and Reid (1965).

Udder capacity was measured on a subset of cows (18 cows/treatment) at wk $-1,3$, and 5 based on the method of Carruthers et al. (1993). Briefly, cows were not milked for $40 \mathrm{~h}$ and then milked out normally. Cows were then injected (intramuscularly) with $10 \mathrm{IU}$ of oxytocin and milked again within 1 min to remove residual milk. The remaining cows (12 cows/treatment) underwent biopsies (mammary, adipose, and liver) at wk $-1,3$, and 5 . Biopsy data are not presented in this paper.

Blood samples were collected on $1 \mathrm{~d}$ each week after the a.m. milking for 2 wk pre- until 10 wk posttreatment initiation, and then on $1 \mathrm{~d}$ every $2 \mathrm{wk}$ for $4 \mathrm{wk}$, and $1 \mathrm{~d}$ per month thereafter. Samples were collected from the coccygeal vein of each cow into a $10-\mathrm{mL}$ evacuated blood tube containing $100 \mathrm{IU}$ of sodium heparin/ $\mathrm{mL}$, placed on ice and centrifuged at $1,120 \times g$ for 12 min at $4^{\circ} \mathrm{C}$. Plasma was harvested and stored at $-20^{\circ} \mathrm{C}$ before analyses for glucose, insulin, IGF-I, growth hormone (GH), BHBA, and NEFA. Insulin (Hales and Randle, 1963), IGF-I (Gluckman et al., 1983), and GH (Downing et al., 1995) were measured in duplicate by double-antibody RIA, with inter- and intraassay CV $<6 \%$. The NEFA, glucose, and BHBA analyses were performed at $37^{\circ} \mathrm{C}$ on a Modular P800 analyzer (Roche,
Basel, Switzerland) by Gribbles Veterinary Pathology Ltd. (Hamilton, New Zealand). The inter- and intraassay CV were $<2 \%$.

\section{Statistical Analysis}

Pretreatment measurements were used as a covariate, and means of daily data for each week and time period (i.e., wk 1 to 3,4 to 12,13 to 23 ) were calculated for individual cows. These data were analyzed using mixed models fitted with REML in GenStat (Payne et al., 2009), including cohort, FL, MF, and the interaction of $\mathrm{FL}$ and $\mathrm{MF}$ as fixed effects and cow as a random effect. Means presented in the tables and figures are those produced from the REML analyses. Differences were considered significant at $P<0.05$, and a trend declared at $P<0.10$.

\section{RESULTS}

\section{Milk Production and Udder Capacity}

During the treatment period (wk 1 to 3 ), yields of milk, ECM, and milk components were less in cows that were UF compared with AF, and in cows milked $1 \times$ relative to $2 \times$ (Table 1 ; Figure 1 ). Interactions existed between FL and MF for milk, ECM, protein, and lactose yields such that the decrease due to $1 \times$ milking was less in UF than AF cows (14 vs. $21 \%, 14$ vs. $20 \%$, 12 vs. $21 \%$, and 16 vs. $24 \%$, for yields of milk, ECM, protein, and lactose, respectively).

The temporal pattern of ECM is depicted in Figure 1. During wk 1, UF $2 \times$ cows produced $17 \%$ less ECM relative to $\mathrm{AF} 2 \times$ cows, and the reduction was greater as the treatment period continued (23 and $35 \%$ less ECM at wk 2 and 3 , respectively). During wk $1, \mathrm{AF} 1 \times$ cows produced $20 \%$ less ECM compared with AF $2 \times$ cows and continued to produce 21 and $20 \%$ less milk at wk 2 and 3 , respectively. Cows that were UF and milked $1 \times$ $(\mathrm{UF} 1 \times)$ had the greatest decrease in milk production, producing $29 \%$ less ECM during wk 1 compared with AF $2 \times$ cows and 34 and $43 \%$ less ECM at wk 2 and 3 , respectively.

Posttreatment, when all cows were AF and milked $2 \times$, we found no interactions between FL and MF on milk production; however, we did observe carryover effects of both UF and $1 \times$ milking (Table 1; Figure 1). During wk 4 to 12 , cows previously UF produced less milk, ECM, and fat (7\%), and less protein and lactose $(8 \%)$ than AF cows (Table 1; Figure 1); however, during wk 13 to 23 , we found no effect of previous underfeeding on the yield of milk or milk components. Cows previously milked $1 \times$ produced less milk $(6 \%)$, ECM $(5 \%)$, fat (4\%), protein (5\%), and lactose $(6 \%)$ 


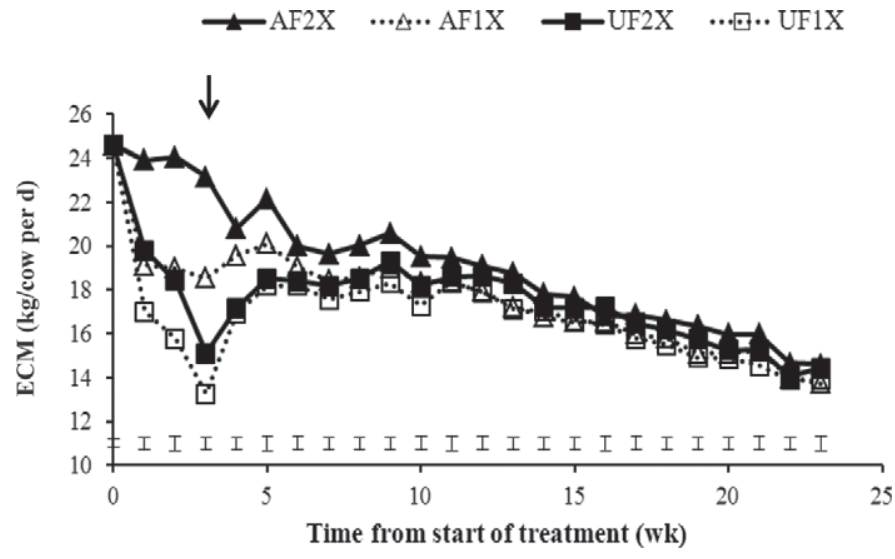

Figure 1. Energy-corrected milk (kg/cow per d) from grazing cows (34 \pm 6 DIM) adequately fed (AF; $14.3 \pm 3.6 \mathrm{~kg}$ of DMI $/$ cow per d) or underfed (UF; $8.3 \pm 2.9 \mathrm{~kg}$ of DMI/cow per d) and milked twice $(2 \times)$ or once $(1 \times)$ daily for 3 wk. Following the treatment period, all cows were milked $2 \times$ and offered a generous pasture allowance to target grazing residuals $>1,600 \mathrm{~kg}$ of $\mathrm{DM} /$ ha for $20 \mathrm{wk}$. Vertical bars represent the standard error of the difference, and the end of the imposed treatments is denoted by an arrow. than those continually milked $2 \times$, and these differences remained during wk 13 to 23 .

At the end of the treatment period (wk 3), udder capacity was $22 \%$ less in UF cows compared with $\mathrm{AF}$ cows $[15.9$ and $20.5 \mathrm{~kg}$ milk/cow per d, respectively; standard error of the difference (SED) $0.76 ; P<0.001$. At wk 5 (2 wk posttreatment), udder capacity was $9 \%$ less in UF cows relative to AF cows $(19.9$ and $18.2 \mathrm{~kg}$ of milk/cow per d, respectively; SED 0.78; $P<0.05$ ). Milking frequency had no effect on udder capacity at either wk 3 (18.0 and $17.6 \mathrm{~kg}$ milk/cow per d for $1 \times$ and $2 \times$ respectively; SED 0.75) or wk 5 (19.4 and 18.7 $\mathrm{kg}$ milk/cow per $\mathrm{d}$ for $1 \times$ and $2 \times$, respectively; SED 0.77 ) and no interaction existed between FL and MF.

\section{Milk Composition}

During the treatment period, milk composition was affected by FL and MF (Table 1). Cows that were UF had greater milk fat concentration, but no change in milk lactose or SCC was found compared with cows that were AF. In contrast, cows that were milked $1 \times$ had no change in milk fat concentration, but had lower

Table 1. Milk production from grazing cows (34 \pm 6 DIM) adequately fed (AF; $14.3 \pm 3.6 \mathrm{~kg}$ of DMI/cow per d) or underfed (UF; $8.3 \pm 2.9$ $\mathrm{kg}$ of DMI/cow per d) and milked twice $(2 \times)$ or once $(1 \times)$ daily for $3 \mathrm{wk}$

\begin{tabular}{|c|c|c|c|c|c|c|c|c|c|}
\hline Variable & Week $^{1}$ & \multicolumn{4}{|c|}{ Treatment } & $\mathrm{SED}^{2}$ & \multicolumn{3}{|c|}{$P$-value ${ }^{3}$} \\
\hline \multirow[t]{2}{*}{ Milk $(\mathrm{kg} / \mathrm{d})$} & 1 to 3 & 22.65 & 17.81 & 16.30 & 14.09 & 0.41 & $<0.001$ & $<0.001$ & $<0.001$ \\
\hline & 13 to 23 & 15.12 & 14.22 & 14.68 & 13.83 & 0.52 & 0.02 & 0.26 & 0.95 \\
\hline \multirow[t]{2}{*}{ ECM $(\mathrm{kg} / \mathrm{d})$} & 1 to 3 & 23.71 & 18.89 & 17.77 & 15.34 & 0.50 & $<0.001$ & $<0.001$ & 0.001 \\
\hline & 4 to 12 & 20.14 & 18.83 & 18.39 & 17.86 & 0.47 & 0.01 & $<0.001$ & 0.24 \\
\hline \multirow{2}{*}{ Fat $(\%)$} & 4 to 12 & 4.33 & 4.36 & 4.30 & 4.45 & 0.10 & 0.20 & 0.70 & 0.40 \\
\hline & 13 to 23 & 4.60 & 4.61 & 4.62 & 4.81 & 0.13 & 0.31 & 0.25 & 0.34 \\
\hline \multirow{3}{*}{ Protein (\%) } & 1 to 3 & 3.55 & 3.54 & 3.18 & 3.28 & 0.03 & 0.01 & $<0.001$ & 0.02 \\
\hline & 4 to 12 & 3.70 & 3.72 & 3.64 & 3.72 & 0.04 & 0.03 & 0.19 & 0.26 \\
\hline & 13 to 23 & 3.86 & 3.85 & 3.82 & 3.90 & 0.05 & 0.37 & 0.96 & 0.26 \\
\hline \multirow{2}{*}{ Lactose (\%) } & 1 to 3 & 4.92 & 4.71 & 4.92 & 4.73 & 0.03 & $<0.001$ & 0.53 & 0.62 \\
\hline & 4 to 12 & 4.83 & 4.84 & 4.79 & 4.78 & 0.02 & 0.86 & $<0.001$ & 0.90 \\
\hline \multirow{2}{*}{ Protein $(\mathrm{kg} / \mathrm{d})$} & 4 to 12 & 0.70 & 0.66 & 0.64 & 0.62 & 0.02 & 0.01 & $<0.001$ & 0.25 \\
\hline & 13 to 23 & 0.58 & 0.54 & 0.56 & 0.53 & 0.02 & 0.03 & 0.23 & 0.77 \\
\hline \multirow{3}{*}{ Lactose $(\mathrm{kg} / \mathrm{d})$} & 1 to 3 & 1.11 & 0.84 & 0.80 & 0.67 & 0.02 & $<0.001$ & $<0.001$ & $<0.001$ \\
\hline & 4 to 12 & 0.92 & 0.86 & 0.84 & 0.80 & 0.02 & $<0.001$ & $<0.001$ & 0.52 \\
\hline & 13 to 23 & 0.72 & 0.68 & 0.70 & 0.66 & 0.03 & 0.03 & 0.28 & 0.98 \\
\hline \multirow[t]{3}{*}{$\mathrm{SCC}(\log )$} & 1 to 3 & 1.62 & 1.89 & 1.68 & 1.81 & 0.07 & $<0.001$ & 0.76 & 0.15 \\
\hline & 4 to 12 & 1.78 & 1.85 & 1.78 & 1.87 & 0.07 & 0.08 & 0.86 & 0.80 \\
\hline & 13 to 23 & 1.89 & 1.84 & 1.87 & 1.89 & 0.09 & 0.92 & 0.82 & 0.57 \\
\hline
\end{tabular}

${ }^{1}$ Week 1 to 3 = treatment period; week 4 to 12 and 13 to 23 = posttreatment periods. Following the treatment period, all cows were milked $2 \times$ and offered a generous pasture allowance to target grazing residuals $>1,600 \mathrm{~kg}$ of DM/ha for $20 \mathrm{wk}$.

${ }^{2}$ Standard error of the difference.

${ }^{3} \mathrm{MF}=$ milking frequency; $\mathrm{FL}=$ feeding level; $\mathrm{MF} \times \mathrm{FL}=\mathrm{MF}$ by $\mathrm{FL}$ interaction. 
Table 2. Body condition score (1 to 10 scale), BW, and concentrations of plasma hormone and metabolites from grazing cows (34 \pm 6 DIM) adequately fed $(\mathrm{AF} ; 14.3 \pm 3.6 \mathrm{~kg}$ of $\mathrm{DMI} /$ cow per d) or underfed (UF; $8.3 \pm 2.9 \mathrm{~kg}$ of DMI/cow per d) and milked twice $(2 \times)$ or once $(1 \times)$ daily for $3 \mathrm{wk}$

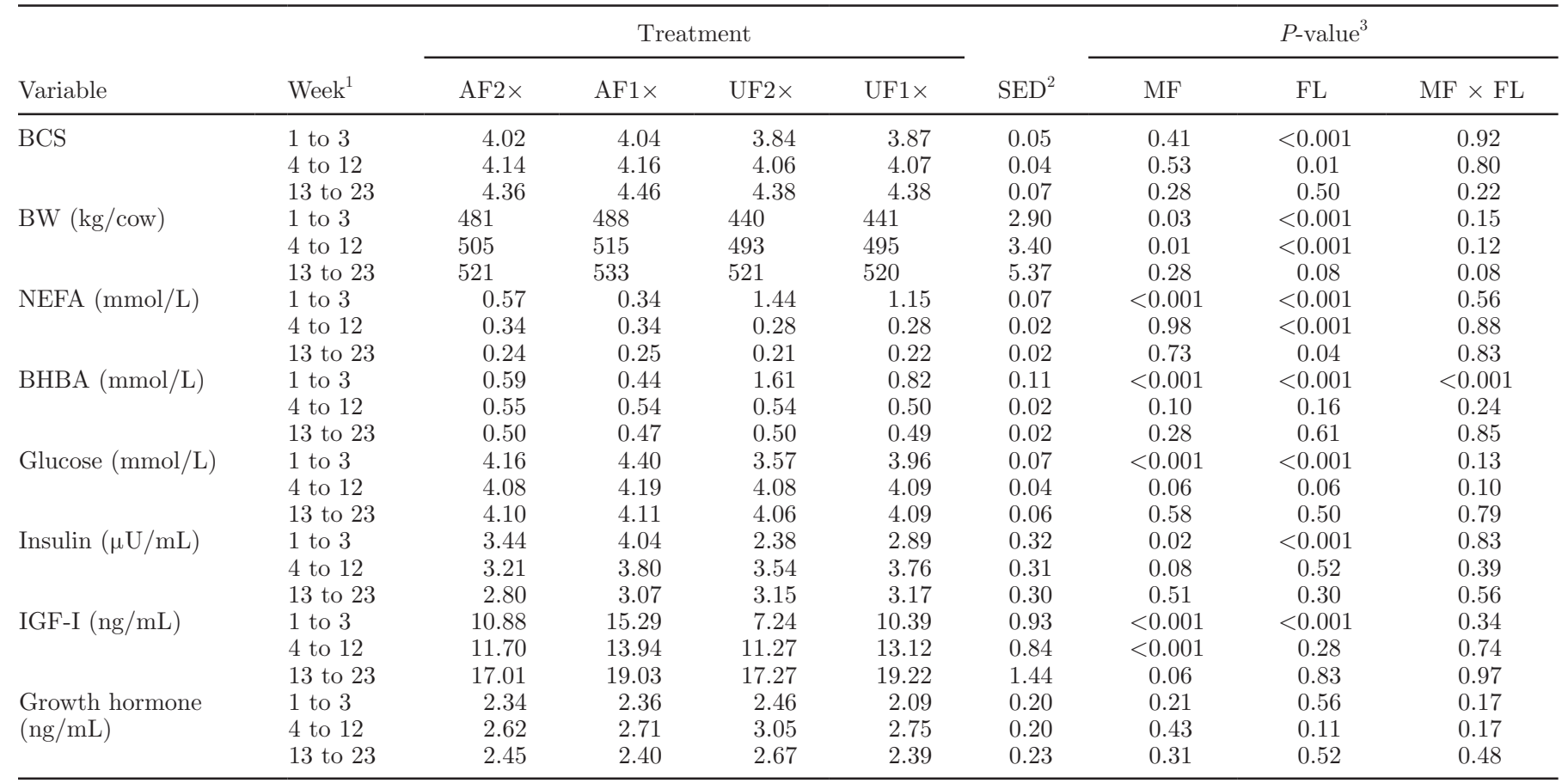

${ }^{1}$ Week 1 to $3=$ treatment period; week 4 to 12 and 13 to $23=$ posttreatment periods. Following the treatment period, all cows were milked $2 \times$ and offered a generous pasture allowance to target grazing residuals $>1,600 \mathrm{~kg}$ of DM/ha for $20 \mathrm{wk}$.

${ }^{2}$ Standard error of the difference.

${ }^{3} \mathrm{MF}=$ milking frequency; $\mathrm{FL}=$ feeding level; $\mathrm{MF} \times \mathrm{FL}=\mathrm{MF}$ by FL interaction.

milk lactose concentration and greater SCC relative to those milked $2 \times$. An interaction existed between FL and MF for milk protein, such that milk protein concentration was less in UF compared with AF cows and was only greater with $1 \times$ milking in UF cows.

No interactions were observed posttreatment. During wk 4 to 12 and wk 13 to 23 , underfeeding had no effect on milk fat, protein or SCC concentration; however, during wk 4 to 12 , lactose concentration was less in cows previously UF. Milking cows $1 \times$ did not alter milk fat, lactose, or SCC concentration once cows were returned to $2 \times$ milking; however, during wk 4 to 12 , protein concentration was greater in cows previously milked $1 \times$.

\section{$B C S$ and $B W$}

The effects of UF and $1 \times$ milking on BCS and BW are presented in Table 2 and Figure $2 \mathrm{a}$ and b. During the treatment period, no FL by MF interactions were observed, and cows that were UF had lower BCS and BW than AF cows. The effects of underfeeding on BCS and $\mathrm{BW}$ were immediate (Figure 2a and b): UF cows had BCS 0.2, 0.25, and 0.13 units less and BW 37,
58, and $39 \mathrm{~kg}$ less than $\mathrm{AF}$ cows at wk 1, 2, and 3, respectively. On average during the treatment period, cows milked $1 \times$ had greater BW compared with cows milked $2 \times$, but BCS did not differ.

We observed some carryover effects of UF and $1 \times$ milking on BW and BCS posttreatment. During wk 4 to 12 , cows previously UF had lower BCS and BW compared with AF cows, whereas cows previously milked $1 \times$ did not differ in BCS but had a greater BW relative to those milked $2 \times$. During wk 13 to 23 , UF or $1 \times$ milking had no effect on BCS; however, we observed a trend for a FL by MF interaction for BW, such that $\mathrm{BW}$ was greater in AF cows milked $1 \times$ compared with all other treatments, which did not differ from each other.

\section{Plasma Hormones and Metabolites}

Plasma hormone and metabolite concentrations are presented in Table 2 and Figure $3 \mathrm{a}$ and b. During the treatment period, UF cows had greater plasma BHBA and NEFA concentrations than AF cows. The effects of underfeeding on BHBA and NEFA concentrations were immediate (Figure 3a and b). Peak BHBA and NEFA 
a)

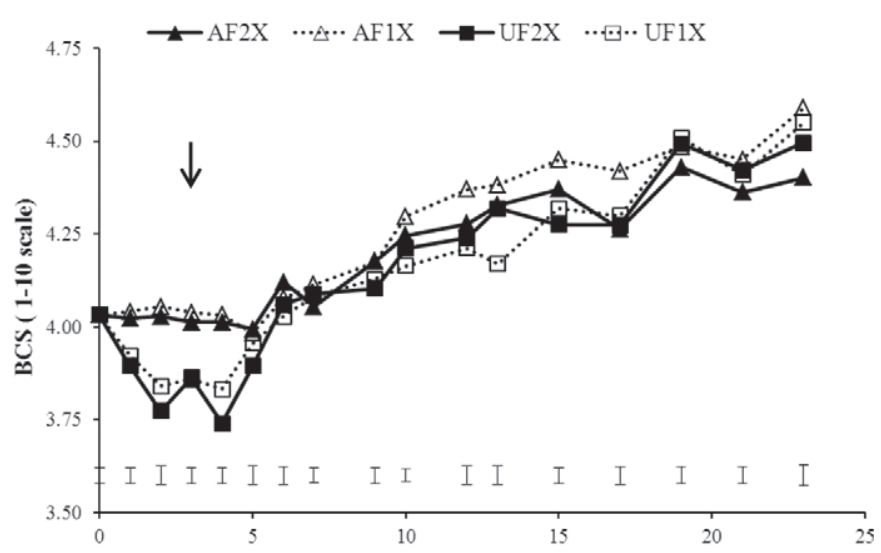

b)

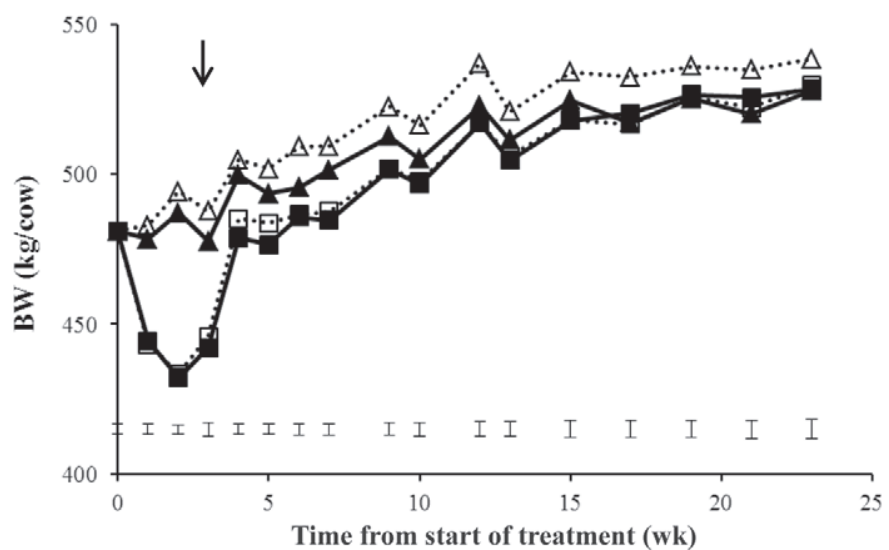

Figure 2. (a) Body condition score (1-10 scale; 1 = emaciated; 10 = obese), and (b) BW from grazing cows (34 \pm 6 DIM) adequately fed (AF; $14.3 \pm 3.6 \mathrm{~kg}$ of DMI/cow per d) or underfed (UF; $8.3 \pm 2.9 \mathrm{~kg}$ of DMI/cow per d) and milked twice $(2 \times)$ or once $(1 \times)$ daily for 3 wk. Following the treatment period, all cows were milked $2 \times$ and offered a generous pasture allowance to target grazing residuals $>1,600 \mathrm{~kg}$ of $\mathrm{DM} /$ ha for $20 \mathrm{wk}$. Vertical bars represent the standard error of the difference, and the end of the imposed treatments is denoted by an arrow.

concentrations occurred at wk 1 , at which point BHBA and NEFA concentrations were 270 and $186 \%$ greater, respectively, in $\mathrm{UF} 2 \times$ compared with $\mathrm{AF} 2 \times$ cows. Although BHBA and NEFA concentrations remained greater during the treatment period, the increase due to underfeeding at wk 2 and 3 was not as great as at wk 1 (Figure 3a and $\mathrm{b}$ ).

Cows milked $1 \times$ had lower BHBA and NEFA concentrations during the treatment period compared with cows milked $2 \times$. A FL by MF interaction effect existed on BHBA concentration, such that the decrease due to $1 \times$ milking was greater in UF cows compared with $\mathrm{AF}$ cows. Similar to UF cows milked $2 \times$, plasma BHBA and NEFA concentrations peaked at wk 1 in UF cows milked $1 \times$; however, BHBA and NEFA concentrations were only 100 and $56 \%$ greater, respectively, than AF $2 \times$ cows. No FL by MF interactions were found for BHBA and NEFA concentrations posttreatment, and no carryover effects of UF on BHBA concentrations were observed. However, during wk 4 to 12 and wk 13 to 23, plasma NEFA concentrations were lower in cows previously UF. No carryover effects were observed of $1 \times$ milking on BHBA or NEFA concentrations.

During the treatment period, plasma glucose, insulin, and IGF-I concentrations were lower in UF cows and

a)

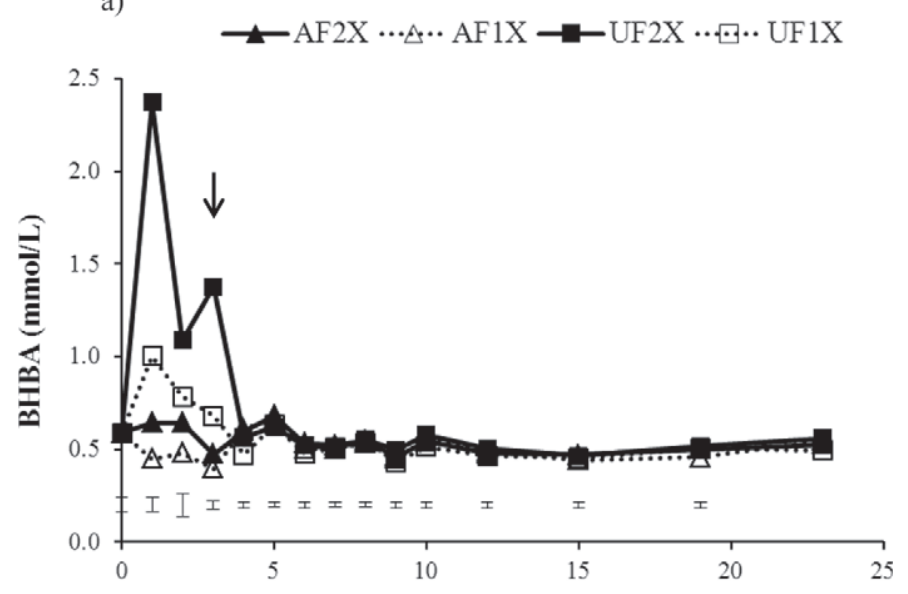

b)

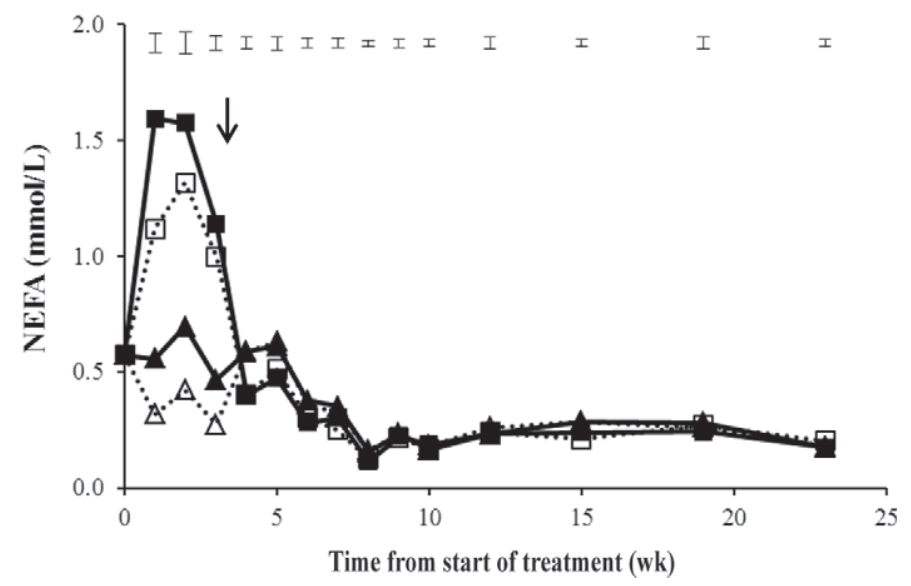

Figure 3. Concentrations of (a) BHBA, and (b) NEFA from grazing cows (34 $\pm 6 \mathrm{DIM})$ adequately fed (AF; $14.3 \pm 3.6 \mathrm{~kg}$ of DMI/cow per d) or underfed (UF; $8.3 \pm 2.9 \mathrm{~kg}$ of DMI/cow per d) and milked twice $(2 \times)$ or once $(1 \times)$ daily for 3 wk. Following the treatment period, all cows were milked $2 \times$ and offered a generous pasture allowance to target grazing residuals $>1,600 \mathrm{~kg}$ of $\mathrm{DM} /$ ha for $20 \mathrm{wk}$. Vertical bars represent the standard error of the difference, and the end of the imposed treatments is denoted by an arrow. 
greater in cows milked $1 \times$, with no MF by FL interactions (Table 2). Posttreatment (wk 4 to 12), glucose concentration tended $(P=0.06)$ to be lower in cows that were previously UF. In cows previously milked $1 \times$, plasma IGF-I concentration was greater and glucose and insulin concentrations tended $(P=0.06$ and $P=$ 0.08 , respectively) to be greater. During wk 13 to 23 , FL or MF had no effect on glucose or insulin concentrations; however, a tendency $(P=0.06)$ existed for greater IGF-I concentration in cows previously milked $1 \times$. Neither FL nor MF affected plasma GH concentrations during the treatment or posttreatment periods.

\section{DISCUSSION}

Milking cows $1 \times$ is a management option sometimes used during feed deficits in an attempt to improve energy status and prevent BCS loss in grazing dairy cows. Data on the immediate and carryover benefits of this mitigation strategy are limited. Results reported here indicate that energy status is improved with $1 \times$ milking but the negative effects on milk production are additional to the losses evoked by underfeeding. The additive long-term losses in milk production due to underfeeding and $1 \times$ milking need to be considered if employing this strategy.

\section{Immediate Effects of Underfeeding and 1× Milking on Milk Production}

Both underfeeding and $1 \times$ milking reduced milk production during the treatment period; however, the milk production profiles differed. During wk 1, milk production was reduced by a similar amount in cows that were UF or milked $1 \times$; however, milk production decreased further in UF cows as the treatment period continued, as cows compensated for the sustained reduction in intake. In cows milked $1 \times$, milk production plateaued until the end of the treatment period. In addition, further losses in milk production occurred when UF cows were milked $1 \times$. These data indicate that different physiological processes regulate the milk production responses to underfeeding and $1 \times$ milking.

The hypothesis that independent regulatory pathways govern mammary uptake and utilization of nutrients when MF and FL are reduced was proposed by Guinard-Flament et al. (2007) and supported when mRNA expression of mammary genes from purified mammary epithelial cells (MEC) was measured (Boutinaud et al., 2008). Boutinaud et al. (2008) reported that in restricted cows $(\sim 24 \%$ decrease in DMI), a $50 \%$ reduction in transcript abundance of glucose transporter-1 occurred, with no change in $\alpha-\mathrm{LA}$, galactosyltransferase, $\kappa$-CN, $\beta$-cell CLL/lymphoma 2 (BCL2), or BCL2- associated $\mathrm{X}$ protein. In comparison, cows that were milked $1 \times$ had reduced $\alpha-\mathrm{LA}$ and $\kappa-\mathrm{CN}$, and increased BCL2 and BCL2-associated X protein, but no change in glucose transporter- 1 mRNA expression. These data indicate that feed restriction and $1 \times$ milking alter glucose uptake and milk synthesis differently. During feed restriction, the decreased supply of glucose to MEC and associated downregulation of glucose transporter-1 indicate that the entry of glucose to MEC may be more limiting than the capacity of MEC to synthesize lactose. In contrast, with $1 \times$ milking, the downregulation of genes involved in lactose synthesis and the lack of an effect on glucose transporter-1, indicates that lactose and subsequent milk synthesis may be regulated by changes in MEC activity and number, and not nutrient extraction (Boutinaud et al., 2008). In agreement with this, Grala et al. (2011) reported that in grazing dairy cows milked $1 \times$, transcription of genes involved in milk synthesis was downregulated, whereas that of genes involved in apoptosis was upregulated. The lower plasma glucose concentrations in UF compared with AF cows and greater glucose concentrations in cows milked $1 \times$ compared with $2 \times$ in the present experiment are also consistent with this hypothesis. The results presented here, in conjunction with published data, indicate that milking cows $1 \times$ decreases the capacity of MEC to synthesize lactose, even when adequate nutrients (i.e., glucose) are available, whereas, when cows are UF, it may be the uptake of nutrients by the MEC that limits the synthesis of lactose and milk.

Although additional losses in milk production occurred when UF cows were milked $1 \times$, the effects of MF and FL were not completely additive. The loss in milk production with $1 \times$ milking in UF cows was not as great as in AF cows (14 vs. $20 \%$ decrease in ECM, respectively). This difference may be explained by the mechanisms responsible for milk loss with $1 \times$ milking. When MF is reduced, milk accumulates in the mammary gland and leads to increased distension of mammary alveoli and permeability of MEC (Davis et al., 1999). These changes generally occur after approximately 18 $\mathrm{h}$ of milk accumulation and stimulate local signals to reduce milk secretion (Stelwagen et al., 1997). In AF cows, where milk production was greater, more milk accumulates during the intermilking interval, resulting in an earlier and greater negative feedback signal and a greater negative effect on milk production compared with UF cows (Davis et al., 1999; Stelwagen, 2001). These data are consistent with Auldist and Prosser (1998), who measured a greater milk production loss when well-fed grazing cows were switched to $1 \times$ milking for $2 \mathrm{~d}$, compared with restricted (20 vs. 14\%). Additionally, Rémond et al. (2002) reported that the decrease in milk yield due to $1 \times$ milking tended to be 
greater in cows fed a normal compared with a low energy ration (32 vs. $23 \%$ ). However, this hypothesis does not explain the consistent decrease in milk production ( $14 \%$ decrease in ECM) due to $1 \times$ milking in UF cows throughout the 3 -wk treatment period, even though milk yield continued to decrease in response to underfeeding. This apparent inconsistency may be due to the fact that mammary capacity of UF cows also decreased during the treatment period by a similar amount to the decrease in milk production $(\sim 22 \%)$, such that the accumulation of milk in proportion to the mammary capacity in UF $1 \times$ cows was similar at wk 1,2 , and 3 . Further research is required to better understand the factors involved in milk synthesis regulation over time in UF cows milked $1 \times$.

In addition to changes in milk yield, reducing FL and MF altered milk composition. Protein concentration decreased with underfeeding, probably due to both a deficiency in metabolizable protein supply and a deficiency in ME, thus limiting ruminal microbial protein synthesis, amino acid peptide bond synthesis, uptake of essential amino acids by the mammary gland, and subsequent milk protein production. This is consistent with previous studies in which similar intake restrictions imposed for short-term periods during early lactation (Roche, 2007; Gross et al., 2011) resulted in a reduction in milk protein concentration.

In contrast to milk protein, milk fat concentration was greater in UF compared with AF cows, most probably due to the greater mobilization of NEFA and incorporation into milk fat of these cows. The greater milk fat concentration with underfeeding is consistent with Roche (2007); however, others have reported no effect of feed restriction on milk fat concentration (Guinard-Flament et al., 2007; Gross et al., 2011) or decreased milk fat concentration with underfeeding (Rémond et al., 2002). The different milk fat responses between these studies may be due to the severity and duration of underfeeding and the different effect on body tissue mobilization as indicated by plasma NEFA responses in these studies. Both the present study and Roche (2007) reported substantial increases in NEFA concentrations to $>1 \mathrm{mmol} / \mathrm{L}$ during the period of underfeeding, whereas Guinard-Flament et al. (2007) and Gross et al. (2011) reported only moderate increases in NEFA concentration in UF cows, and Rémond et al. (2002) measured no change in plasma NEFA concentration when cows were fed a lower energy diet.

The effects of $1 \times$ milking on milk composition are variable (Davis et al., 1999); typically, cows milked $1 \times$ have greater milk protein, fat, and SCC, and lower milk lactose concentrations (Davis et al., 1999). Consistent with this, in the present study, cows milked $1 \times$ had lower milk lactose concentration and greater SCC. The greater SCC associated with $1 \times$ milking does not appear to be due to clinical or subclinical mastitis infection, but is probably attributed to increased neutrophil numbers and decreased milk volume yield (Stelwagen and Lacy-Hulbert, 1996; Lacy-Hulbert et al., 2005). In the present study, protein concentration was only greater with $1 \times$ milking in UF cows and no change in milk fat concentration was observed. The effects of MF on milk composition appear to differ, depending on milk volume, stage of lactation, and duration of $1 \times$ milking, and were small compared with the changes in daily milk yield.

\section{Immediate Effects of Underfeeding and 1× Milking on Energy Status and Metabolism}

We observed an immediate effect of underfeeding on proxies of energy status. Based on the elevated plasma BHBA and NEFA concentrations, UF cows were in a state of severe negative energy balance within the first week of underfeeding because the decrease in energy output was not as great as the decrease in energy intake (17 and $42 \%$ decrease for energy output and intake, respectively). In UF cows milked $2 \times$, concentrations of plasma BHBA and NEFA peaked at wk 1, with herd BHBA concentrations reaching levels indicative of clinical ketosis (2.0 mmol/L; Oetzel, 2004). This situation mimics the third stage of fuel homeostasis or "early starvation phase" (Newsholme and Leech, 1983), where NEFA (from increased lipolysis) and ketone bodies are oxidized to fuel peripheral tissues and support milk production. Although the UF cows were not "starved" per se, a $42 \%$ decrease in energy intake in early lactating cows is a severe restriction and would elicit both homeostatic and homeorhetic changes to ensure glucose or ketone bodies were available for use by vital organs, which cannot oxidize NEFA for energy (Newsholme and Leech, 1983).

As the treatment period continued, milk production decreased further in UF cows, compensating for the continued underfeeding and improving the associated negative energy status. Although during wk 2 and 3, plasma BHBA and NEFA concentrations were still greater in UF cows compared with AF cows, the difference was substantially less than during wk 1 , indicating that NEFA and ketone body demand and production were reduced, due to the decrease in energy output via reduced milk production. Gross et al. (2011) restricted early- to mid-lactation cows (100 DIM) by $30 \%$ for 3 wk and reported peak NEFA concentrations at wk 1, after which point they gradually declined. Although absolute values of NFEA were greater in the current study, perhaps due to cows being in an earlier stage of lactation, the temporal pattern of NEFA concentration 
during the treatment period was similar. Lower concentrations of plasma glucose, insulin, and IGF-I in UF cows are consistent with others (Roche, 2007; Gross et al., 2011) and reflect the negative energy status of the UF cows during the 3 -wk treatment period.

In contrast to underfeeding, blood constituents measured in the present study indicated an immediate improvement in energy status of all cows milked $1 \times$. The decreased energy output (via reduced milk production) in cows milked $1 \times$, reduced the requirement for energy supplying processes such as gluconeogenesis, lipolysis, fatty acid $\beta$-oxidation, and ketogenesis, and provided immediate physiological benefits, for UF cows in particular. In the present study, average circulating concentrations of BHBA and NEFA, were reduced by 58 and $30 \%$, respectively, in UF cows milked $1 \times$ compared with UF cows milked $2 \times$. Peak plasma BHBA concentration did not exceed $1.0 \mathrm{mmol} / \mathrm{L}$ in UF cows milked $1 \times$, indicating that these animals were at less risk of ketosis (Oetzel, 2004) compared with UF cows milked $2 \times$. The improved energy status with $1 \times$ milking is consistent with previous research based on calculated individual energy balance and proxies thereof (Auldist and Prosser, 1998; Rémond et al., 2002; GuinardFlament et al., 2007).

As energy balance and associated circulating metabolites and hormones are linked to reproductive performance (see review by Garnsworthy et al., 2008), it has been proposed that $1 \times$ milking may also improve reproductive parameters in grazing dairy cows (Clark et al., 2006). Although reproductive parameters were not measured in the present study, a similar feed restriction imposed immediately before the planned start of mating (80 DIM) evoked a 7\% decrease in the 6 -wk in-calf rate of grazing cows (Burke et al., 2010). Further research is required to determine if the improved energy balance, and greater glucose, insulin, and IGF-I concentrations from cows milked $1 \times$ may reduce the postpartum anestrus interval and improve reproductive performance in grazing dairy cows.

Although $1 \times$ milking improved energy balance and BW of UF cows, all UF cows lost 0.2 BCS units during the 3-wk feed restriction and this BCS loss was not altered by $1 \times$ milking. This lack of an effect may be because BCS is a relatively crude measure of energy status and is not measured on a continuous scoring system, therefore subtle changes in energy stores may not have been detected using this method. Additional ultrasonographic measures, such as backfat thickness and longissimus dorsi muscle diameter, may have provided more accurate measures of body fat and protein mobilization and replenishment, both during and after the feed restriction (Gross et al., 2011).

\section{Carryover Effects of Underfeeding and 1× Milking on Milk Production}

In the present study, we observed negative carryover effects after 3 wk of underfeeding, with ECM reduced by $4 \%$ for the subsequent 20 wk. It appears that the residual effect of underfeeding depends on the severity and duration of the intake restriction, the stage of lactation, and the immediate effect on milk production. Roche (2007) imposed a similar feed restriction (36\%) for 5 wk postcalving, which evoked an immediate $23 \%$ decrease in ECM and a continued $11 \%$ decrease for 10 wk after, whereas Gross et al. (2011) restricted DMI by $50 \%$, in cows at 100 DIM, but only reduced milk production by $10 \%$ with no residual effect on milk yield. The physiological reasons for the carryover effect of underfeeding need to be investigated further. The immediate effect of short-term underfeeding on MEC blood supply and nutrient uptake (Guinard-Flament et al., 2007; Boutinaud et al., 2008) and the decreased MEC activity and number following longer periods of underfeeding (Norgaard et al., 2005; Dessauge et al., 2011) may all play roles in the residual effect of underfeeding on milk production.

We also found negative carryover effects of $1 \times$ milking on milk production, with cows previously milked $1 \times$ producing $5 \%$ less ECM for the following $20 \mathrm{wk}$. In a review of $1 \times$ milking studies, Rémond and Pomiès (2005) suggested that the carryover effects of $1 \times$ milking differ depending on the stage of lactation of the cows and the duration of $1 \times$ milking. In support of the duration effect, no negative carryover effect was found after 1 wk of $1 \times$ milking (Loiselle et al., 2009); however, subsequent milk production decreased $7 \%$ following 3 to 6 wk of $1 \times$ milking (Guinard-Flament et al., 2011; Phyn et al., 2011) and this increased to a carryover loss of 10 to $15 \%$ following $10 \mathrm{wk}$ of $1 \times$ milking (Rémond and Pomiès, 2005). However, in contrast, Rémond et al. (2002) reported that the negative effects of 3 wk of $1 \times$ milking were reversible, such that when MF was increased, there were no long-term production losses. However, statistical power was limited in their study and the low cow numbers $(n=6$ /treatment) combined with a large between-cow variability in the milk production response to $1 \times$ milking (Holmes et al., 1992; Littlejohn et al., 2010; Guinard-Flament et al., 2011) may have influenced results. The negative carryover effect on milk production is most probably due to the continued reduction in MEC activity and number, even after cows are changed to $2 \times$ milking (Grala et al., 2011). Although MEC have not yet been analyzed from the present experiment, the continued reduction in milk production following $1 \times$ milking indicates long-term, 
irreversible changes to MEC population when MF was reduced for $3 \mathrm{wk}$ in early lactation.

\section{Carryover Effects of Underfeeding and 1× Milking on Energy Balance and Metabolism}

Although milk production remained reduced after cows had returned to $2 \times$ milking and adequate intake, minimal changes in energy balance occurred after the treatment period. During wk 4 to 12, BHBA concentration was not affected by FL or MF, and differences in plasma NEFA concentration were opposite to effects during the treatment period; NEFA concentration was less in cows previously UF compared with AF. The lower NEFA concentration at this time was probably because the UF cows produced less ECM (7\%) during the carryover period (wk 4 to 12) while being offered the same pasture allowance as AF cows. This may reflect a greater partitioning of energy toward tissue reserves to recover from the BCS loss (Roche et al., 2009).

Plasma glucose and insulin concentrations tended to remain greater during wk 4 to 12 in cows previously milked $1 \times$; however, this trend was primarily due to differences in wk 5; from wk 6 onward, MF had no effects on glucose or insulin concentrations. The only blood constituent that remained altered after the treatment period was IGF-I, which was greater during wk 4 to 12 , and tended to be greater during wk 13 to 23 , in cows previously milked $1 \times$.

\section{CONCLUSIONS}

Milking cows $1 \times$ during a feed deficit reduced milk production by more than the feed deficit alone. Data support the hypothesis that changes to FL and MF alter milk production via different physiological processes. Although BCS did not change measurably with $1 \times$ milking, plasma hormones and metabolites indicated an improved energy status with $1 \times$ milking in both AF and UF cows. We observed residual negative effects of both UF and $1 \times$ milking on milk production, although effects on energy status were minimal after cows had returned to $2 \times$ milking and adequate intakes. Immediate and long-term responses in milk production and energy status need to be considered when deciding on $1 \times$ milking as a management strategy during an acute feed deficit.

\section{ACKNOWLEDGMENTS}

The authors gratefully acknowledge DairyNZ (Hamilton, New Zealand) farm and technical staff for implementation of this experiment and Barbara Dow for statistical analysis. They also thank David Lindsay (formerly of University of Western Australia, Perth, Australia) for his advice on writing style. This research was funded by New Zealand dairy farmers through DairyNZ Inc. (\#AN802) and the Ministry of Business, Innovation and Employment (\#DRCXO801).

\section{REFERENCES}

Auldist, M. J., and C. G. Prosser. 1998. Differential effects of shortterm once-daily milking on milk yield, milk composition and concentrations of selected blood metabolites in cows with low or high pasture intake. Proc. N.Z. Soc. Anim. Prod. 58:41-43.

Boutinaud, M., M. H. Ben Chedly, E. Delamaire, and J. GuinardFlament. 2008. Milking and feed restriction regulate transcripts of mammary epithelial cells purified from milk. J. Dairy Sci. 91:988-998.

Broster, W. H. 1974. Response of the dairy cow to level of feeding. Pages 14-34 in Bien. Rev. NIRD. National Institute for Research in Dairying (NIRD), Shingfield, UK.

Bryant, A. M., and T. E. Trigg. 1974. Immediate and longer term response of dairy cows to level of nutrition in early lactation. Proc. N.Z. Soc. Anim. Prod. 39:139-147.

Burke, C. R., Y. J. Williams, L. Hofmann, J. K. Kay, C. V. C. Phyn, and S. Meier. 2010. Effects of an acute feed restriction at the onset of the seasonal breeding period on reproductive performance and milk production in pasture-grazed dairy cows. J. Dairy Sci. 93:1116-1125.

Carruthers, V. R., S. R. Davis, A. M. Bryant, H. V. Henderson, C. A. Morris, and P. J. A. Copeman. 1993. Response of Jersey and Friesian cows to once a day milking and prediction of response based on udder characteristics and milk composition. J. Dairy Res. 60:1-11.

Clark, D. A., C. V. C. Phyn, M. J. Tong, S. J. Collis, and D. E. Dalley. 2006. A systems comparison of once- versus twice-daily milking of pastured dairy cows. J. Dairy Sci. 89:1854-1862.

Davis, S. R., V. C. Farr, and K. Stelwagen. 1999. Regulation of yield loss and milk composition during once-daily milking: A review. Livest. Prod. Sci. 59:77-94.

Dessauge, F., V. Lollivier, B. Ponchon, R. Bruckmaier, L. Finot, S. Wiart, E. Cutullic, C. Disenhaus, S. Barbey, and M. Boutinaud. 2011. Effects of nutrient restriction on mammary cell turnover and mammary gland remodeling in lactating dairy cows. J. Dairy Sci. 94:4623-4635.

Downing, J. A., J. Joss, P. Connell, and R. J. Scaramuzzi. 1995. Ovulation rate and the concentrations of gonadotrophic and metabolic hormones in ewes fed lupin grain. J. Reprod. Fertil. 103:137-145.

Garnsworthy, P. C., K. D. Sinclair, and R. Webb. 2008. Integration of physiological mechanisms that influence fertility in dairy cows. Animal 2:1144-1152.

Gluckman, P. D., J. J. Johnson-Barrett, J. H. Butler, B. W. Edgar, and T. R. Gunn. 1983. Studies of insulin-like growth factor-I and -II by specific radioligand assays in umbilical cord blood. Clin. Endocrinol. (Oxf.) 19:405-413.

Grala, T. M., C. V. C. Phyn, J. K. Kay, A. G. Rius, M. D. Littlejohn, R. G. Snell, and J. R. Roche. 2011. Temporary alterations to milking frequency, immediately post-calving, modified the expression of genes regulating milk synthesis and apoptosis in the bovine mammary gland. Proc. N.Z. Soc. Anim. Prod. 71:3-8.

Gross, J., H. A. van Dorland, R. M. Bruckmaier, and F. J. Schwarz. 2011. Performance and metabolic profile of dairy cows during a lactational and deliberately induced negative energy balance with subsequent realimentation. J. Dairy Sci. 94:1820-1830.

Guinard-Flament, J., E. Delamaire, P. Lamberton, and J. L. Peyraud. 2007. Adaptions of mammary uptake and nutrient use to oncedaily milking and feed restriction in dairy cows. J. Dairy Sci. 90:5062-5072. 
Guinard-Flament, J., S. Lemosquet, E. Delamaire, G. le Bris, P. Lamberton, and C. Hurtaud. 2011. Alteration of the nutrient uptake by the udder over an extended milking interval in dairy cows. J. Dairy Sci. 94:5458-5468.

Hales, C. N., and P. J. Randle. 1963. Immunoassay of insulin with insulin-antibody precipitate. Biochem. J. 88:137-146.

Holmes, C. W., G. F. Wilson, D. D. S. MacKenzie, and J. Purchas. 1992. The effects of milking once daily throughout lactation on the performance of dairy cows grazing on pasture. Proc. N.Z. Soc. Anim. Prod. 52:13-16.

Lacy-Hulbert, S. J., D. E. Dalley, and D. A. Clark. 2005. The effects of once a day milking on mastitis and somatic cell count. Proc. N.Z. Soc. Anim. Prod. 65:137-142.

Littlejohn, M. D., C. G. Walker, H. E. Ward, K. B. Lehnert, R. G. Snell, G. A. Verkerk, R. J. Spelman, D. A. Clark, and S. R. Davis. 2010. Effects of reduced frequency of milk removal on gene expression in the bovine mammary gland. Physiol. Genomics 41:21-32.

Loiselle, M. C., C. Ster, B. G. Talbot, X. Zhao, G. F. Wagner, Y. R. Boisclair, and P. Lacasse. 2009. Impact of postpartum milking frequency on the immune system and the blood metabolite concentration of dairy cows. J. Dairy Sci. 92:1900-1912.

McNamara, S., J. J. Murphy, F. P. O'Mara, M. Rath, and J. F. Mee. 2008. Effect of milking frequency in early lactation on energy metabolism, milk production and reproductive performance of dairy cows. Livest. Sci. 117:70-78.

Newsholme, E. A., and A. R. Leech. 1983. The integration of metabolism during starvation, refeeding and injury. Pages 536-561 in Biochemistry for the Medical Sciences. John Wiley \& Sons Ltd., Chichester, UK.

Nørgaard, J., A. Sorensen, M. T. Sorensen, J. B. Andersen, and K. Sejrsen. 2005. Mammary cell turnover and enzyme activity in dairy cows: Effects of milking frequency and diet energy density. J. Dairy Sci. 88:975-982.

Oetzel, G. R. 2004. Monitoring and testing dairy herds for metabolic disease. Vet. Clin. North Am. Food Anim. Pract. 20:651-674

Patton, J., D. A. Kenney, J. F. Mee, F. P. O’Mara, D. C. Wathes, M Cook, and J. J. Murphy. 2006. Effect of milking frequency and diet on milk production, energy balance, and reproduction in dairy cows. J. Dairy Sci. 89:1478-1487.

Payne, R. W., D. A. Murray, S. A. Harding, D. B. Baird, and D. M. Soutar. 2009. GenStat for Windows, 12th Edition. Introduction. VSN International Ltd., Hemel Hempstead, UK.
Phyn, C. V. C., J. K. Kay, A. G. Rius, S. R. Morgan, C. S. Roach, T. M. Grala, and J. R. Roche. 2011. Effect of temporary alterations to milking frequency during the early post-partum period on milk production and body condition score in grazing dairy cows. Proc. N.Z. Soc. Anim. Prod. 71:45-49.

Rémond, B., S. Aubailly, Y. Chilliard, D. Dupont, D. Pomiès, and M. Petit. 2002. Combined effects of once-daily milking and feeding level in the first three weeks of lactation on milk production and enzyme activities, and nutritional status, in Holstein cows. Anim. Res. 51:101-117.

Rémond, B., J.-B. Coulon, M. Nicloux, and D. Levieux. 1999. Effects of temporary once-daily milking in early lactation on milk production and nutritional status of dairy cows. Ann. Zootech. 48:341-352.

Rémond, B., and D. Pomiès. 2005. Once-daily milking of dairy cows: A review of recent French experiments. Anim. Res. 54:427-442.

Renwick, J., A. Clark, G. Griffiths, J. Hendrix, B. Liley, B. Tait, and S. Wood. 2010. State of climate 2010: A snapshot of recent climate in New Zealand. National Institute of Water and Atmospheric Research (NIWA), Auckland, New Zealand.

Roche, J. R. 2007. Milk production responses to pre- and post-calving dry matter intake in grazing dairy cows. Livest. Sci. 110:12-24.

Roche, J. R., P. G. Dillon, C. R. Stockdale, L. H. Baumgard, and M. J. VanBaale. 2004. Relationships among international body condition scoring systems. J. Dairy Sci. 87:3076-3079.

Roche, J. R., N. C. Friggens, J. K. Kay, M. W. Fisher, K. J. Stafford, and D. P. Berry. 2009. Invited review: Body condition score and its association with dairy cow productivity, health and welfare. J. Dairy Sci. 92:5769-5801.

Stelwagen, K. 2001. Effect of milking frequency on mammary functioning and shape of the lactation curve. J. Dairy Sci. 84(ESuppl.):E204-E211.

Stelwagen, K., V. C. Farr, H. A. McFadden, C. G. Prosser, and S. R. Davis. 1997. Time course of milk accumulation-induced opening of mammary tight junctions and blood clearance of milk components. Am. J. Physiol. 273:R379-R386.

Stelwagen, K., and S. J. Lacy-Hulbert. 1996. Effect of milking frequency on milk somatic cell count characteristics and mammary secretory cell damage in cows. Am. J. Vet. Res. 57:902-905.

Tyrrell, H. F., and J. T. Reid. 1965. Prediction of the energy value of cow's milk. J. Dairy Sci. 48:1215-1223. 